\title{
PELAKSANAAN PENGKAJIAN KEPERAWATAN PADA PASIEN DIABETES MELITUS DI RUMAH SAKIT
}

\author{
Erta Iman Jelita Harefa/181101138 \\ ertahrf08@gmail.com
}

\begin{abstract}
Abstrak
Latar belakang: Pengkajian keperawatan merupakan tahapan dalam mengidentifikasi data-data, mengumpulkan informasi yang berkesinambungan secara terus-menerus terhadap kondisi pasien/klien. Pada tahapan ini, pelaksanaan pengkajian keperawatan yang dilakukan pada pasien diabetes melitus. Diabetes melitus (DM) merupakan suatu gangguan metabolisme karbohidrat, protein dan lemak akibat dari kurangnya keseimbangan antara ketersediaan insulin dengan kebutuhan insulin.

Tujuan: Penulisan ini bertujuan untuk mengetahui dan memberi informasi tentang pelaksanaan pengkajian keperawatan pada pasien diabetes melitus di rumah sakit.

Metode: Penulisan ini menggunakan metode literature review dengan pendekatan jurnal atau artikel, buku dan $e$-book yang relevan dan akurat serta berfokus pada pelaksanaan pengkajian keperawatan pada pasien diabetes melitus di rumah sakit. Adapun jurnal atau artikel dan e-book yang digunakan pada literature review adalah jurnal atau artikel dan e-book yang didapatkan dengan menggunakan Google Scholar, Portal Garuda, dan Jurnal Keperawatan Indonesia.

Hasil: Berdasarkan hasil pencarian literatur didapatkan pengkajian keperawatan pada pasien diabetes melitus yang terdiri dari pengumpulan data (wawancara, pemeriksaan fisik, pemeriksaan diagnostik maupun laboratorium, dan dokumen rekam medik), pemeriksaan atau klasifikasi data, melakukan validasi data, pengelompokkan data, penentuan/identifikasi masalah dan dokumentasi data.

Pembahasan: Penyakit diabetes melitus ini sangat memerlukan penanganan yang intensif dan kompherensif oleh perawat melalui tindakan pengkajian keperawatan sebab penyakit ini memberikan dampak peningkatan angka kematian.

Penutup: Pada tahapan ini, pelaksanaannya di berbagai rumah sakit baik nasional maupun internasional telah terlaksana dan melakukannya walaupun ada beberapa rumah sakit nasional kurang maksimal dalam melaksanakannya. Untuk itu bagi para perawat muda ataupun calon perawat dibutuhkan sebagai agent of change yang memberikan pelayanan kesehatan menjadi lebih maju dan bermutu.
\end{abstract}

Kata kunci: pelaksanaan, pengkajian keperawatan, diabetes melitus 


\section{LATAR BELAKANG}

Pengkajian keperawatan merupakan tahapan dalam mengidentifikasi datadata, mengumpulkan informasi yang berkesinambungan secara terus-menerus terhadap kondisi pasien/klien. Adapun metode yang digunakan dalam melakukan pengkajian keperawatan yaitu wawancara, pengkajian fisik, pemeriksaan diagnostik dan laboratorium, serta dokumen rekam medik (Deswani, 2009).

Dasar pemikiran dari pengkajian adalah suatu perbandingan, ukuran atau penilaian mengenai keadaan pasien/klien dengan menggunakan norma, nilai, prinsip, aturan, harapan, teori, dan konsep yang berkaitan dengan permasalahan (Dion \& Betan, 2015).

Pada tahapan ini, pelaksanaannya di berbagai rumah sakit baik nasional maupun internasional telah terlaksana dan melakukannya tetapi kurang maksimal.

Dalam hal ini pengkajian keperawatan yang dibahas disini adalah pengkajian keperawatan pada pasien diabetes melitus.

Diabetes melitus (DM) merupakan suatu gangguan metabolisme karbohidrat, protein dan lemak akibat dari kurangnya keseimbangan antara ketersediaan insulin dengan kebutuhan insulin. Diabetes melitus adalah kelainan metabolisme akibat berkurangnya hormon insulin baik kekurangan relatif maupun absolut. Berdasarkan hasil penelitian departemen kesehatan yang di publikasikan pada tahun 2008 menunjukkan angka prevalensi DM di Indonesia sebesar 5,7\% yang berarti lebih dari 12 juta penduduk Indonesia saat ini menderita DM (Hartini, 2007). Diabetes melitus saat ini menjadi salah satu diantara penyakit menular yang akan meningkat jumlahnya di masa datang sebab diabetes melitus sudah menjadi ancaman utama bagi kesehatan. Berdasarkan WHO membuat perkiraan bahwa pada tahun 2000 jumlah pengidap diabetes diatas umur 20 tahun berjumlah 150 juta orang dan dalam kurun waktu 25 tahun kemudian, jumlah itu akan membesar menjadi 300 juta orang. WHO pada september 2012 menjelaskan bahwa penderita DM di dunia mencapai 347 juta orang dan lebih dari $80 \%$ kematian akan DM terjadi pada negara miskin dan berkembang (Sudoyo, 2006). Berdasarkan hasil penelitian yang dilakukan WHO di beberapa negara berkembang menunjukkan peningkatan jumlah tertinggi pasien diabetes melitus terjadi di negara asia tenggara termasuk 
Indonesia. Dalam meningkatnya penyakit diabetes melitus di beberapa negara berkembang akibat peningkatan kemakmuran di negara tersebut dan adanya perubahan gaya hidup terutama di kota-kota besar. Meningkatnya kasus diabetes melitus di masyarakat perkotaan sangat erat hubungannya dengan perkembangan status ekonomi dan globalisasi yang memicu terjadinya Perubahan yang diduga akibat perubahan pola makan dari makanan tradisional yang banyak mengandung karbohidrat dan sayur ke pola makan kebarat-baratan dengan komposisi makanan yang terlalu banyak mengandung protein, lemak, gula, garam dan mengandung sedikit serat. Sehingga komposisi makanan tersebut terdapat pada makanan siap saji yang sangat digemari oleh anak-anak muda bahkan orangtua. Selain itu juga cara hidup yang sangat sibuk dengan pekerjaan mulai dari pagi hingga sore bahkan malam hari yang menyebabkan tidak adanya kesempatan berolahraga (Frank, 2010).

Dalam hal ini orang yang mengidap penyakit diabetes melitus ada banyak ditemui di berbagai rumah sakit di Indonesia. Untuk itu dari data diatas sangat perlu penanganan yang intensif agar jumlah atau angka terjadinya diabetes melitus atau kematian akibat DM berkurang. Dalam penanganan penyakit DM dibutuhkan peran perawat dalam melakukan tindakan penanganan melalui proses keperawatan yang dimulai dari tahapan awal yaitu pengkajian keperawatan.

\section{TUJUAN}

Tujuan penulisan ini adalah untuk mengetahui dan memberi informasi tentang pelaksanaan pengkajian keperawatan pada pasien diabetes melitus di rumah sakit.

\section{METODE}

Penulisan ini menggunakan metode literature review dengan pendekatan jurnal atau artikel, buku dan e-book yang relevan dan akurat serta berfokus pada pelaksanaan pengkajian keperawatan pada pasien diabetes melitus di rumah sakit. Adapun jurnal atau artikel dan $e$ book yang digunakan pada literature review adalah jurnal atau artikel dan $e$ book yang didapatkan dengan menggunakan Google Scholar, Portal Garuda, dan Jurnal Keperawatan Indonesia. 


\section{HASIL}

Berdasarkan hasil pencarian literatur di dapatkan pengkajian keperawatan pada pasien diabetes melitus sebagai berikut:

\section{Pengumpulan Data}

Pengumpulan data adalah suatu proses pengkajian dengan mengumpulkan informasi tentang status kesehatan pasien/klien secara sistematis.

Sumber data yang digunakan untuk mengumpulkan data yaitu: a) Pasien/klien, keluarga, dan masyarakat, b) Orang-orang terdekat pasien/klien, c) Catatan keperawatan, d) Rekam medik, e) Konsultasi secara verbal atau tulisan, f) Pemeriksaan diagnostik, g) Literatur yang berkaitan.

Metode yang digunakan dalam pengumpulan data adalah: 1) Wawancara atau sering disebut dengan anamnesa merupakan kegiatan bertanya atau tanya jawab yang berhubungan dengan masalah yang dihadapi pasien/klien. Dalam wawancara yang dilakukan adapun data yang harus diperoleh yaitu identitas diri klien, riwayat perawatan dan kesehatan, kondisi kesehatan yang memerlukan pengobatan, respon terhadap penyakit, faktor sosial, dukungan sosial dan budaya, pola koping, aktivitas seharihari, dan persepsi klien terhadap penyakit yang diderita. Pada wawancara ini bertujuan untuk memperoleh data tentang masalah kesehatan, mendapatkan informasi yang diperlukan dalam mengidentifikasi dan merencanakan tindakan keperawatan, serta meningkatkan hubungan saling percaya antara perawat dengan klien dalam berkomunikasi.

Di dalam wawancara terdapat tahapannya sebagai berikut: tahap persiapan, tahap pembukaan atau perkenalan, tahap kerja, dan tahap terminasi. Di metode pengumpulan data ini ada 2 macam wawancara yaitu: a) Autoanamnesa, yaitu wawancara dengan pasien/klien langsung, dan b) Alloanamnesa, yaitu wawancara dengan keluarga/orang terdekat. 2) Pemeriksaan fisik dimulai dari prosedur yang umum seperti pengukuran tanda-tanda vital dan pemeriksaan head to toe (dari kepala ke kaki). 3) Pemeriksaan diagnostik maupun laboratorium yang terdiri dari pemeriksaan darah, urine dan pemeriksaan lainnya yang bersangkutan dengan penyakit pasien. 4) Dokumen rekam medik.

\section{Pemeriksaan atau Klasifikasi Data}

Pada pemeriksaan atapun klasifikasi data terdapat 2 bagian yaitu 1) Data subjektif 
adalah data yang diperoleh dari keluhan yang dirasakan pasien atau dari keluarga pasien, dan 2) Data objektif adalah data yang diperoleh melalui suatu pengukuran dan pemeriksaan serta pengamatan. Dalam hal ini diperlukan kemampuan mengidentifikasi tanda dan gejala serta membuat keputusan yang tepat akan mempengaruhi keterampilan, pengetahuan, dan keterampilan praktik dalam mengobservasi. Dalam hal ini diperlukan penilaian data dan verifikasi terhadap informasi yang didapat secara nyata dan komplit.

\section{Melakukan Validasi Data}

Dalam melakukan validasi data ini berdasarkan 2 bagian yaitu: 1)

Berdasarkan sistem tubuh, dan 2) Berdasarkan kebutuhan manusia yang menggunakan pendekatan fungsi biopsikososiokultural dan spiritual.

\section{Pengelompokan Data}

Pengelompokan data merupakan suatu bagian yang bertujuan untuk meningkatkan kemampuan dalam menginterpretasikan status kesehatan pasien/klien.

\section{Penentuan atau Identifikasi Masalah}

Identifikasi masalah pasien/klien dibagi menjadi: pasien yang tidak bermasalah tetapi perlu peningkatan status dan fungsi tubuh (kesejahteraan), pasien yang kemungkinan mempunyai masalah (possible problem), pasien yang mempunyai masalah potensial sehingga kemungkinan besar akan mempunyai masalah aktual, resiko atupun sindrom.

\section{Dokumentasi Data}

Dokumentasi data merupakan bagian terakhir dari pengkajian keperawatan yang lengkap. Kelengkapan dalam dokumentasi pengkajian keperawatan sangatlah penting di karenakan semua data yang berkaitan dengan status pasien/klien dapat memberikan informasi yang menunjukkan normalitas maupun abnormalitas.

\section{PEMBAHASAN}

Pengkajian keperawatan adalah tahap awal dari proses keperawatan yang merupakan suatu proses pengumpulan data yang sistematis dari berbagai sumber untuk mengevaluasi dan mengidentifikasi status kesehatan pasien/klien.

Dalam pembahasan ini dibahas tentang pengkajian keperawatan yang dilakukan pada pasien diabetes melitus. Diabetes melitus (DM) adalah penyakit metabolik yang ditandai dengan tingginya kadar glukosa darah (hyperglikemia) sebagai akibat dari kekurangan sekresi insulin 
dan gangguan aktivitas insulin. Untuk itu, penyakit diabetes melitus ini sangat memerlukan penanganan yang intensif dan kompherensif oleh perawat sebab penyakit ini memberikan dampak peningkatan angka kematian.

Penyakit diabetes melitus ini perlu dilakukan pengkajian keperawatan yang bagian dari proses keperawatan. Di dalam pengkajian terdapat beberapa cara dalam mendapatkan informasi dan data yang dibutuhkan oleh seorang perawat.

Dalam pengkajian keperawatan sangat dibutuhkan informasi lengkap dan akurat mengenai masalah diabetes melitus yang dimana dalam data memuat klasifikasi atau tipe diabetes melitus yang dialami oleh pasien/klien, mengetahui faktor penyebab dari diabetes melitus dan komplikasi diabetes melitus.

Sehingga pengkajian keperawatan memberikan suatu gambaran mengenai masalah yang dialami pasien/klien dan melakukan perencanaan tindakan yang akan dilakukan serta mengambil keputusan tindakan untuk menunjang kesehatan pasien yang lebih maksimal.

\section{PENUTUP}

Pengkajian keperawatan merupakan tahapan dalam mengidentifikasi datadata, mengumpulkan informasi yang berkesinambungan secara terus-menerus terhadap kondisi pasien/klien. Pengkajian keperawatan yang dibahas adalah pengkajian pada pasien diabetes melitus. Diabetes melitus (DM) adalah penyakit metabolik yang ditandai dengan tingginya kadar glukosa darah (hyperglikemia) sebagai akibat dari kekurangan sekresi insulin dan gangguan aktivitas insulin. Pada tahapan ini, pelaksanaannya di berbagai rumah sakit baik nasional maupun internasional telah terlaksana dan melakukannya walaupun ada beberapa rumah sakit nasional kurang maksimal dalam melaksanakannya. Untuk itu bagi para perawat muda ataupun calon perawat dibutuhkan sebagai agent of change yang memberikan pelayanan kesehatan menjadi lebih maju dan bermutu.

\section{REFERENSI}

Damayanti, S. (2017). Diabetes Melitus dan Penatalaksanaan Keperawatan. Yogyakarta: Nuha Medika.

Darliana, D. (2011). Manajemen Asuhan Keperawatan Pada Pasien Diabetes Melitus. Idea Nursing Journal, 132-135. 
Deswani. (2009). Proses Keperawatan dan Berpikir Kritis. Jakarta: Salemba Medika.

H. R., Hasdianah. (2017). Mengenal Daibetes Melitus Pada Orang Dewasa dan Anak-Anak Dengan Solusi Herbal. Yogyakarta: Nuha Medika.

Misnadiarly. (2006). Diabetes Melitus:

Gangren, Ulcer, Infeksi, Mengenal Gejala, Menanggulangi, dan Mencegah Komplikasi. Edisi 1. Jakarta: Pustaka Populer Obor.

Mulyati, Sri. (2014). Asuhan Keperawatan Pada Pasien Diabetes Melitus Dalam Konteks Keperawatan Kesehatan Masyarakat Perkotaan di Ruang Rawat Penyakit Dalam Gedung A RSUPN Cipto Mangunkusumo Jakarta. Depok: FIKUI

Nurjannah, I. (2010). Proses Keperawatan. Yogyakarta: MocoMedia.

Nursalam. (2009). Proses dan Dokumentasi Keperawatan: Konsep dan Praktik. Jakarta: Salemba Medika.
Rahmi Yosmar, dkk. (2018). Survei Risiko Penyakit DM Terhadap Masyarakat Kota Padang, Jurnal Sains Farmasi dan Klinis, 5(2):134.

Rima Ulfa, Fahra, dkk. (2017). Hubungan Perawat Sebagai Edukator Dengan Perawatan Diri Pasien DM Tipe 2 di Poli Penyakit Dalam Rumah Sakit Bina Sehat Jember, Nursekine Journal, 2(1): 64.

Rumahorbo, H. (2014). Mencegah Diabetes Melitus Dengan Perubahan Gaya Hidup. Bogor: In Media.

Sari, Retno N. (2017). Diabetes Melitus. Yogyakarta: Nuha Medika.

Simamora, R. H. (2008). Peran Manajer Dalam Pembinaan Etika Perawat Pelaksana Dalam Peningkatan Kualitas Pelayanan Asuhan Keperawatan. Jurnal IKESMA.

Simamora, R. H. (2009). Dokumentasi Proses Keperawatan. Jember University Press.

Simamora, R. H. (2010). Komunikasi Dalam Keperawatan. Jember University Press. 
Slamet, Suryono. (2006).

Penatalaksanaan Diabetes

Terpadu. Jakarta: EGC.

Sudoyo, A. W. (2006). Buku Ajar Ilmu

Penyakit Dalam. Edisi 4. Jakarta:

Departemen Ilmu Penyakit

Dalam FKUI. 